\title{
International Trade, Foreign Direct Investment (FDI) and International Technology Transfer: A Comparative Study of Asian and African Economies
}

\author{
*Olawumi Dele Awolusi, Ezekiel Jide Fayomi, GANIYU Idris Olayiwola \\ University of KwaZulu-Natal, South Africa \\ *awolusi@ukzn.ac.za,21357440@stu.ukzn.ac.za, ganiyui@ukzn.ac.za
}

\begin{abstract}
This paper investigates the long-run equilibrium relationships and short-term effect of international trade and Foreign Direct Investment (FDI) on international technology transfers in selected African and Asian countries from 1980 to 2013.The Johansen and Juselius multivariate co-integration technique and the granger causality test was used to test these relationships. The findings confirmed the presence of co-integrating vectors in the models of these countries. The outcome of the test posits short-run causal relationships, which run either bidirectionally or unidirectionally in all the variables for the selected countries. However, the most interesting lesson for many developing countries in Africa and Asia is that this study confirmed that international technology transfers supported domestic investment, economic growth, exports and imports of goods and services in some of these countries. Finally, all the variables in each model adjusted to equilibrium in the long-run, except for domestic investment in the Malaysian, Nigerian and Indian systems. The study thereby suggests an improved government policies and regulatory framework to improve international technology transfers, domestic investment, economic growth, and exports and imports of goods and services.
\end{abstract}

Keywords: International Technology Transfer, Foreign Direct Investment, Trade, Vector Error Correction Modeling, Africa, Asia

\section{Introduction}

There is increasing debate in both theoretical and empirical literature concerning the perceived benefits of a country's openness to trade (Fosfuri, Motta \& Ronde, 2001; Meyer, 2004; Usman and Ibrahim, 2012; Anyanwu \& Yameogo, 2015). The general feeling is that traditional analyses often minimize the cost of protectionism (Saggi, 2002). Underlying this assumption is the belief that international trade, foreign direct investment (FDI), and the interaction among countries in numerous other forms - all contribute to improvement in the global allocation of physical resources and transmitting technology worldwide (Dollar, 1992; Sachs \&Andrew, 1995; Iršová \& Havránek, 2013). It is also important to know that technology or knowledge is often transferred at a cost, and most empirical evidence observes the difficulties in transferring technology internationally (Sasidharan \& Ramanathan, 2007; Lee \& Tan, 2006; Havránek \& Iršová, 2010). Consequently, spillovers in many developing countries of Asian and African economies (Anyanwu, 2012; Hailu, 2010; Lee \& Tan, 2006). In addition, many studies in developing countries also justifies the imperative of technology as an important tool of economic growth, improved balance of trade and poverty reduction, in the present global economic environment (Anyanwu, 2012; Reece \& Sam, 2012; Tian, 2007; Mohamed \& Sidiropoulos, 2010). This is on the premise that the process of acquiring and increasing the number of technology transfers and people with the requisite knowledge, skills and experience invariably increases the level of economic growth in many developing countries (Saggi, 2002, Lim, 2001). Many developing nations are interested in technology transfers to local population to improve growth, productivity, and to reduce inequality and poverty (Hailu, 2010; Reece \& Sam, 2012; Mohamed \& Sidiropoulos, 2010). Specifically, Okejiri (2000) and Mohamed and Sidiropoulos (2010) studies on Nigeria and MENE countries observed that on average, nations that have sustained high levels of technology transfers are also those who have, higher levels of economic growth and development.

Consequently, it is imperative for Asian, African, and other developing economies to maintain a high level of technology transfers, trade and FDI mostly from developed economies (UNCTAD, 2009; Okejiri, 2000). This may also increase the level comparative advantages for these developing economies (Mohamed and Sidiropoulos, 2010; UNCTAD, 2015). Based on the above the importance of technology transfers, FDI, economic growth in many Asian and African economies cannot be overemphasized (Anyanwu, 2012; UNCTAD, 2015). This is based on the important contributions of Africa and Asian countries to world economic growth, as well as, reference model for other developing economies (Anyanwu, 2012; UNDP, 2007). 
However, manytheoretical and empirical studies have also supported improved absorptive capacity in many developing countries, in order for the benefits from FDI and trade to be realized (Reece \& Sam, 2012; Tian, 2007; Lim, 2001). It is also argued that while many scholars have succeeded in outlining the various potential channels for international technology transfers to many developing countries, little is known in practice and in theory about the importance of these channels and also how exactly this transmission occurs; hence this lack impact of FDI and international trade on technology transfers, an examination of the role of FDI and international trade as veritable channels of international technology transfer to many developing countries is imperative (Saggi, 2002; Tian, 2007; Mohamed \& Sidiropoulos, 2010). The purpose of this study was thus to determine the effects of international trade and FDI on international technology transfers. Specific objectives are: (1) to investigate the long-run equilibrium relationships among international factors (FDI, international technology transfer, and international technology transfer to the selected countries. This paper is divided into five sections. Section one is the introduction which covers the general background of the study, objectives and gaps in the literature. In section 2 a review of related studies is undertaken. Section three focuses on the methodology. Section four presents the results and discusses the findings. Lastly, section five presents the conclusion, policy implications, and the limitations of the study.

\section{Literature Review}

The importance of FDI and trade in the present 'globalised' economies cannot be over emphasized. For instance, the global value of FDI was quoted at about US\$650 billion between the 1970s and 1980s (UNCTAD, 2009). This, however, rose from US $\$ 710.8$ billion in 2004 to US $\$ 1.7$ trillion in 2011 (UNCTAD, 2013: xxi). According to Aregbesola (2014), of these increases, Africa's stock grew from US $\$ 44$ billion in 2010 to US\$50 billion in 2012(UNCTAD, 2013:3). In addition to the physical movement of capital, multinational corporations (MNCs) also assisted in shaping the landscape of the world economy (Anyanwu \& Yameogo, 2015). Their exports accounted for about a third of the total world exports of goods and services between 2009 and 2012 (UNCTAD, 2013), while the number of people employed by these enterprises worldwide was more than $12 \%$ of the world population in 2008. These significant roles indicate why countries across the world initiate sustainable policy frameworks that will not only attract FDI from these MNCs, but also retain it (Mohamed \& Sidiropoulos, 2010; Aregbesola, 2014).

Technological Diffusion through Inward FDI and International Trade: According to Markusen (1995), the Dunning Eclectic model is the dominant model in identifying the impact of ITT by foreign firms in the contemporary literature. Also known as the Ownership, Location and Internalization (OLI) model, this model posits that firm-specific assets (e.g. knowhow, processes and product patents) are usually used at no extra cost in more than one location (factory), in two or more countries(Markusen, 1995; Al Nasser, 2010).This model explains the penchant for(Lloyd, 1996).In all, the relationships between the diverse channels of international technology transfer are complex. According to Hoekman, Maskus and Saggi (2004), while FDI and international trade are often complements, Licensing and FDI may be either substitutes or complements.Thepositive spillover affects the impact of new technology in the host economy and management knowhow via manifestation to other stakeholders - and deliberate development of new technologies via research and development is also a veritable tool in technology transfers(Lloyd, 1996).

Resources could be in disembodied like licenses, patents, designs and brand names, embodied resources are usually in the form of competences like management skills. He therefore posited that technique, knowledge. Given the background of the Lloyd (1996) and Granstrand (1998) studies, much of the literature stresses the need to transfer technology - disembodied or embodied - from one country to another (Lee \& Tan, 2006). According to Deme and Graddy (2006), while assuming that endogenously determined knowledge capital and knowledge spillovers contribute to growth, endogenous growth theories also suggest that knowledge accumulated through research and development often creates externalities. This could be by simultaneously increasing the productivity of firms conducting for example the R\&D, and any other firms who choose to adopt the technology. In addition to Romer's (1986) argument that trade speeds up the diffusion of newly produced knowledge, Grossman and Helpman (1990) also affirm that as a firm trades products that use knowledge capital, others benefit from the direct use of the product in their production process, and through the imitated knowledge capabilities in the product. In summary, most of these theories emphasize that 
international trade and FDI significantly contribute to knowledge transfers, chiefly via the process of imitation (Usman \& Ibrahim, 2012; Reece \& Sam, 2012; Deme \& Graddy, 2006).

Foreign Direct Investment and Trade in the Asia Pacific: In Asian countries, the mode and purpose of international technology transfer have witnessed dramatic changes over the years. The 'Asian Tigers' (South Korea, Taiwan, Singapore and Hong Kong), were the first set of countries to open up their economies through the introduction of market-driven policies, while other countries like Malaysia and China followed (Agarwal, Gupta \& Gandhi, 2005). In support of the classical theory of trade, Malaysia is one of the recipients of the upsurge inflow of FDI into Asia since the mid-1980s - whether through investment or from the developed economies (Lloyd, 1996). Malaysia enjoyed these upsurges in both FDI and international trade due to its initial cheap labour and the provision of basic infrastructure in comparison with other developing countries (Agarwal et al., 2005). However, the movement of the Asian Tigers' capacity in the low-tech to foreign export policy, helped the emergence of both the second and third tier of the 'new aspiring industrialized' countries like Malaysia tremendously. However, the initial comparative advantages have been increasingly upgraded to industrial exports and capacities (Kojima, 2000; Lemoine \& Ünal-Kesenci, 2004). With less than US\$100million in 1970, Malaysia witnessed a dramatic increased in FDI inflows in the 1980s, due largely to its open economy and favourable investment climate. The FDI inflows peaked in the early 1990s, with an annual average of over US $\$ 5$ billion from 1990 to 1996 - shortly before the Asian financial crises. Malaysia's comparative advantage started in early the 1980s until shortly after the financial crises, due to favourable policies - especially in the electronics sector (Leete, 2006; WTO, 2001). Despite the huge impact of the financial crises, Malaysia still benefit from favourable FDI locations among the Southeast Asian countries, while FDI policies have been translating into better GDP per capita for Malaysians. Over the last decade, most sectors in Malaysia have benefited from FDI and international trade via the strategy of foreign technical collaborations. Consequently, the international However, despite the shift from innovations in many developing countries of Asia, efforts are still being made towards improving the rate of technology transfer through import of relevant technology from developed countries (Agarwal et al., 2005).Malaysia has been enjoying comparative advantages in the importation of machinery and capital goods from developed countries - mostly the US and Japan. This to some extent facilitated the acquisition of approved strategic and relevant high technology by the Malaysian local firms compared to most developing economies (Mohamed \& Sidiropoulos, 2010; Jiménez, 2011).

Growth over the past two decades- through an export-oriented industrialization strategy (Pupphavesa \& Grewe, 1994; Lee \& Tan, 2006). This was a counter-strategy to the failing international commercial policies of the 1980s (Craig, 2001; Lee \& Tan, 2006). Consequently, incentives manufacturing. The economy experienced dramatic export growth, notwithstanding this inconsistent policy (Pupphavesa \&Grewe, 1994; Lee \& Tan, 2006). FDI into Thailand accelerated by the second half of the 1980 s, from US $\$ 354$ million in 1987 to a peak ofUS $\$ 2.5$ billion in it has been increasing steadily to over US $\$ 8.6$ billion in 2006 (WTO, 2007). Although FDI inflow into Malaysia and South Africa (and Nigeria, in the early 1970s) far outweighed that of Thailand, from the 1970s to late 1990s, this was probably due to Thailand being a less open economy and the imposition of various impediments to trade (Lee \& Tan, 2006). Conversely, the situation has changed since 2000. Thailand experienced improved economic growth from 1980 until the recent financial crisis (Klenow \& RodriguezClare, 1997; Diao \& Stokke, 2005). The broad empirical background for technology transfer in Thailand and most Asian countries can be drawn from Equipment, and hence spillovers are linked to international trade (Urata \& Yokota, 1994). In addition, using the analysis of Collins and Bosworth (1996), Young (1994) estimated Total Factor Productivity (TFP) growth in Thailand to be approximately 2\%. This TFP growth from 1981-1995 was traced to a policy of openness and the sectoral allocation of employment (Urata \& Yokota, 1994; Diao \& Stokke, 2005).

Foreign Direct Investment (FDI) and International Trade in Africa: The integration of many African countries with the global economy increased in the 1990s. This was facilitated by changes in economic policies and the reduction in trade barriers (Imoudu, 2012). This is on the premise that FDI benefits developing countries via supplementary domestic investment, as well as technology transfer, employment generation, improved local competition, and other positive externalities (Ayanwale, 2007; Ayanwale \& Bamire, 2004). However, according to the Heckscher - Ohlin Theorem, countries will usually export goods whose production is highly intensive, and with abundant factors of production (Mahe, 2005). This is 
important because a few countries in Africa - especially Nigeria, South Africa, Morocco and Egypt - attract diversified FDI that is both service and resources-related (Aregbesola, 2014). Most African countries attract FDI in primary resources like crude oil, coal, platinum and gold, and strive to attract foreign FDI because of its perceived influence on economic growth and development. Notable initiatives like the New Partnership for Africa's Development (NEPAD) also enhance the attraction of FDI for many African countries. For example, the amount of FDI inflow into Nigeria increased from US\$2.23 billion in 2003 to about to US\$9.44 in 2006 (Imoudu, 2012; Anyanwu \& Yameogo, 2015). The extent of FDI contributions to economic growth in Nigeria have been subjected to tremendous debate in the literature, especially as Nigeria is undoubtedly confronted with both economic and social problems of high poverty, a high level of unemployment, corruption, low capacity utilization, and income inequality (Ayanwale \& Bamire, 2004; Akinlo, 2004; Jiménez, 2011). These results on the linkage between FDI and economic growth in Nigeria are however not unanimous (Oyejide, 2005; Akinlo, 2004). Another major hindrance to economic growth is the fact that FDI has traditionally been concentrated in the Nigerian extractive industries - which are usually non-growth generators (Kandil, 2011; Imoudu, 2012; Iršová \& Havránek, 2013).

In frantic efforts to attract FDI, South Africa has implemented various policy initiatives in the last two decades. South Africa thus enjoys a comparative advantage in attracting capital-intensive FDI and the attendance technology transfers in Africa (Borensztein, Gregorio \& Lee, 1998; Kandil, 2011), due to the implementation of both policy (product market regulation, openness to trade, labour-market arrangements, infrastructural development and corporate tax rates) and non-policy (factor proportion, market size, economic and political stability) factors (Fedderke \& Romm, 2004). Confirming the positive spill-over from FDI and trade on output using aggregated time-series data in South Africa, Fedderke and Romm (2004) also confirmed the positive influence of FDI on growth from 1960 to 2002. In addition, their study also observed a crowd-out of domestic investment from FDI - although this impact is restricted in the short-run (Mazenda, 2014). In a similar study, Sridharan, Vijayakumar and Chandra (2009) also studied the causal relationship between FDI and growth in the BRICS countries, using quarterly data from 1999 to 2007 for China, from 1992 to 2007 for India, and from 1990 to 2007 for South Africa (Mazenda, 2014). The results showed bi-directional relationships between FDI and growth for South Africa, while only a unidirectional relationship was observed for China and India. However, unemployment, regardless of the various macroeconomic policies, is still the major hindrance in terms of the realization of the desired economic growth (Havránek \& Iršová, 2010; Al Nasser, 2010; Mazenda, 2014).

\section{Methodology}

Selected countries in Africa and Asia, from 1980 to 2012, were utilized in this study. Craig (2001) and Lee and Tan (2006) suggested a comparative analysis of Asian and African economies - especially the two most populous countries, China and India (Chakraborty \& Basu, 2002; Javorcik, 2004). The selected countries for this study are South Africa, Nigeria, Malaysia, Thailand, China and India. The relationships among FDI, international trade, domestic investment and output were analyzed via multivariate co-integration analysis. This involved the use of Granger-causality tests within a Vector Error-correction Modelling (VECM) framework to analyze the relationships (Johansen \& Juselius, 1990). The secondary data sources were chiefly from: the World Trade Organization (WTO) database, database, International Monetary Fund (IMF), Nigeria National Bureau of Statistics, the Matrade database, the United Nations Statistics database (UNdata), and the World Development Indicators ONLINE.

Econometric Model: The model utilized in this study was exclusively adapted from past empirical and theoretical studies (Madsen, 2007; Lee \& Tan, 2006).These are represented in the following equations:

$$
\begin{aligned}
& \text { IMPMACH }_{t}=\mathrm{a}_{1}+\mathrm{a}_{2} \text { IFDI }_{t}+\mathrm{a}_{3} \operatorname{RGDP}_{t}+\mathrm{a}_{4} \mathrm{HDI}_{t}+\mathrm{a}_{5} \operatorname{HEXP}_{t}+\mathrm{a}_{6} \mathrm{HIMP}_{t}+\varepsilon \ldots . . . \text { equ. (1) } \\
& \text { IFDI }_{t}=\mathrm{b}_{1}+\mathrm{b}_{2} \text { IMPMACH }_{t}+\mathrm{b}_{3} \text { RGDP }_{t}+\mathrm{b}_{4} \mathrm{HDI}_{t}+\mathrm{b}_{5} \operatorname{HEXP}_{t}+\mathrm{b}_{6} \mathrm{HIMP}_{t}+\varepsilon \ldots \text { equ.(2) } \\
& \text { RGDP }_{t}=\mathrm{c} 1+\mathrm{c}_{2} \text { IMPMACH }_{t}+\mathrm{c}_{3} \text { IFDI }_{t}+\mathrm{c}_{4} \mathrm{HDI}_{t}+\mathrm{c}_{5} \mathrm{HEXP}_{t}+\mathrm{c}_{6} \mathrm{HIMP}_{t}+\varepsilon \ldots \text { equ.(3) }
\end{aligned}
$$




$$
\begin{aligned}
& \text { HDI }_{t}=\mathrm{d}_{1}+\mathrm{d}_{2} \text { IMPMACH }_{t}+\mathrm{d}_{3} \text { IFDI }_{t}+\mathrm{d}_{4} \text { RGDP }_{t}+\mathrm{d}_{5} \text { HEXP }_{t}+\mathrm{d}_{6} \mathrm{HIMP}_{t}+\varepsilon \ldots \text { equ. (4) } \\
& \text { HEXP }_{t}=\mathrm{e} 1+\mathrm{e}_{2} \text { IMPMACH }_{t}+\mathrm{e}_{3} \text { IFDI }_{t}+\mathrm{e}_{4} \text { RGDP }_{t}+\mathrm{e}_{5} \mathrm{HDI}_{t}+\mathrm{e}_{6} \mathrm{HIMP}_{t}+\varepsilon \ldots \text { equ. (5) } \\
& \text { HIMP }_{t}=\mathrm{f}_{1}+\mathrm{f}_{2} \text { IMPMACH }_{t}+\mathrm{f}_{3} \text { IFDI }_{t}+\mathrm{f}_{4} \text { RGDP }_{t}+\mathrm{f}_{5} \mathrm{HDI}_{t}+\mathrm{f}_{6} \mathrm{HEXP}_{t}+\varepsilon \ldots . . . \text { Equ. (6) }
\end{aligned}
$$

In the above equations: IMPMACH represents imports of machinery (proxy for technology transfer), IFDI stands for inflow of FDI to host country, and RGDP is the host country's real GDP. HDI stands for host country's domestic investment, HEXP for host country's exports, and HIMP represents the host country's imports. The disturbance is represented by $\varepsilon \ldots$, while the unknown population parameters are represented by a1...a7. From the models, equation (1), for example, has the dependent variable (IMPMACH), which depends on a big set of explanatory variables (IFDI; RGDP; HDI; HEXP; HIMP). A disturbance is inserted into the models because of the likely omission of explanatory variables, aggregation of variables, model specification, functional misspecification, and measurement errors. In addition, it is also important to note the following assumptions of the models above: all explanatory variables have values that are fixed in repeated samples, each $(\varepsilon)$ disturbance is normally distributed, and there is nonexistence of linear relationships among the values of any two or more of the explanatory variables - i.e. absence of perfect multicollinearity (Asteriou \& Hall, 2007). Consequently, the via equation (1). This is on the basis that the Akaike Information Criterion and Schwarz Bayesian Criterion are supported by Eviews in the form of standardized regression results (Asteriou \& Hall, 2007;Lee \& Tan, 2006; Akaike, 1974; Schwarz, 1978).

Unit Root Test: Given that shocks are temporary and effects are eliminated over time in a stationary time series; a formal test for identifying non-stationarity (presence of unit roots) using Eviews, was carried out (see Asteriou \& Hall, 2007). Since the data used in this study - and most often with macroeconomic time series - are often trended and non-stationary (mean is continually rising), being a regression of one series on the other, it is most likely that a significant positive or negative relationship would result, even though they are unrelated. This is the concept of spurious regression, which is a violation of the Classical Linear Regression Model (CLRM) (Granger \& Newbold, 1974; Asteriou \& Hall, 2007).

Standard ADF Test: In order to eliminate autocorrelation, and because error terms are unlikely to be whiten noise, the standard augmented Dickey-Fuller test was performed (Asteriou \& Hall, 2007). This is important because, according to the Solow Growth Model, there are significant structural breaks, which suggests that country-specific conditioning variables can be permanently altered by major shocks (Strazicich, Lee \& Day, 2004). The tested hypothesis during the ADF test is given below:

Hypothesis 1: Null hypothesis (Ho :) = Model has a Unit Root Alternative hypothesis $\left(\mathrm{H}_{1}:\right)=$ Model has no Unit Root

The critical value was compared with the computed result to accept or reject the null hypothesis. If the former is greater (in absolute value) than the latter, the null hypothesis is rejected and no unit root is present.

Phillips-Perron (PP) Test: Given the imperative of uncorrelated error terms and a constant variance assumption of the ADF methodology, the Phillips-Perron test was performed (Asteriou \& Hall, 2007). The tested hypothesis under the PP test is also the same as the one tested for in the ADF test:

Hypothesis 2: Null hypothesis (Ho :) = Model has a Unit Root

Alternative hypothesis $\left(\mathrm{H}_{1}:\right)=$ Model has no Unit Root

The computed value of the test statistic was also compared to the critical value for the PP test in order to reject or accept the null hypothesis. The null hypothesis is rejected, if the former is greater (in absolute value) than the latter.

KPSS-Kwiatkowski-Phillips-Schmidt-Shin Test: Similar to Asteriou and Hall (2007), the tested hypothesis during the KPSS test is given below:

Hypothesis 3: Null hypothesis = Ho: Model is stationary 
Alternative hypothesis $=\mathrm{H}_{1}$ : Model is not stationary

Multivariate Co-integration Analysis: Co-integration was tested using the Johansen approach under group statistics, bearing in mind the Johansen's reduced-rank regression methodology (Cuthbertson, Hall \& Taylor, 1992). Step one was to determine the order of integration; consequently, unit-root was tested on all the variables of each selected countries to determine the level of co-integration, and appropriate models were selected using the Doldado, Jenkinson and Sosvill-Rivero (1990) criterion. The second step was to determine the optimal lag length. Unfortunately, EViews does not allow the automatic detection of the lag length, so this study decided to estimate the model for a few lags and then reduce down to check for the AIC and SBC optimal value (Asteriou \& Hall, 2007). However, given that co-integration only indicates the presence or absence of Granger-causality, it often failed to show the route of causality - hence, this route was decided via VECM(Cuthbertson et al., 1992).This was applied in this research (Lee \& Tan, 2006)

Vector Error Correction Model (VECM): Following the criticism by Sims (1980) of the identification of endogenous and exogenous variables in models of simultaneous equations, he advocated for equal treatment and no distinction between endogenous and exogenous variables. Once the distinction is ignored, all the variables are treated as endogenous. This will, however, lead to the development of the Vector Autoregressive (VAR) models, where all the equations have the same set of regressors (Asteriou \& Hall, 2007). The VAR model is therefore important in testing for causality (Hasbrouk, 1996). This research, however, used the Granger causality test developed by Granger (1969), under VECM, to test for causality among Imports, FDI, technology transfer and international trade. In addition, VECM also facilitated the distinction between longrun and short-run Granger-causality (Masih \& Masih, 1996).

\section{Results and Discussion of Results}

Unit Root Test: With the use of EViews 9.0, lagged dependent variables were automatically selected. This was an attempt to correct for serial correlation (Cuthbertson et al., 1992).

Table 1: ADF-Augmented Dickey Fuller Test Results

\begin{tabular}{lllll}
\hline Variables & $\begin{array}{l}\text { Level } \\
\text { Constant } \\
\text { without Trend }\end{array}$ & $\begin{array}{l}\text { Constant } \\
\text { with Trend }\end{array}$ & $\begin{array}{l}\text { First Difference } \\
\text { Constant } \\
\text { without Trend }\end{array}$ & $\begin{array}{l}\text { Constant } \\
\text { with Trend }\end{array}$ \\
\hline Malaysia(M) & & & & \\
HDI & -1.128695 & -2.245592 & $-5.190527^{*}$ & $-5.110880^{*}$ \\
HEXP & 3.834168 & 0.697322 & $-3.199933^{* *}$ & $-4.325263^{*}$ \\
IFDI & -1.440994 & -2.572330 & $-7.200976^{*}$ & $-7.096229^{*}$ \\
RGDP & 2.932019 & -0.662914 & $-4.238610^{*}$ & $-5.174591^{*}$ \\
HIMP & 1.843983 & -0.778404 & $-4.414912^{*}$ & $-4.963164^{*}$ \\
IMPMACH & 1.492769 & -1.215579 & $-4.902542^{*}$ & $-5.428332^{*}$ \\
Thailand(T) & & & & \\
HDI & -1.144648 & -2.945136 & $-4.788712^{*}$ & $-4.709925^{*}$ \\
HEXP & 3.714916 & 0.791333 & -1.521439 & $-5.965081^{*}$ \\
IFDI & 1.021374 & 1.505314 & 0.607969 & $-4.552479^{*}$ \\
RGDP & 2.720547 & -1.191821 & $-3.302965^{* *}$ & $-3.907973^{* *}$ \\
HIMP & 1.908789 & -0.216484 & $-3.788318^{*}$ & $-4.137955^{* *}$ \\
IMPMACH & 0.645126 & -2.572635 & $-4.555648^{*}$ & $-4.852589^{*}$ \\
Nigeria(N) & & & & \\
HDI & & & & $-3.361598^{* * *}$ \\
HEXP & 0.124335 & -0.309808 & $-3.145541^{* *}$ & $-3.687529^{* *}$ \\
IFDI & 2.514984 & 1.442281 & $-3.301828^{* *}$ & $-6.088482^{*}$ \\
RGDP & 0.993062 & -0.704361 & $-5.639046^{*}$ & $-6.722904^{*}$ \\
HIMP & 0.172443 & -3.352558 & $-6.807686^{*}$ & $-4.563187^{*}$ \\
IMPMACH & -0.282022 & -0.737150 & $-4.567816^{*}$ & $-6.405380^{*}$ \\
& 1.268557 & -0.224709 & $-5.805208^{*}$ & \\
\hline
\end{tabular}




\begin{tabular}{lllll}
\hline South Africa(S) & & & & \\
HDI & -1.176535 & 1.287363 & $-4.3838827^{*}$ & $-2.222880^{*}$ \\
HEXP & 3.275633 & 0.838877 & $-3.8376673^{* *}$ & $-4.376747^{*}$ \\
IFDI & -2.986794 & -2.848493 & $-7.238377^{*}$ & $-4.383773^{*}$ \\
RGDP & 1.345519 & -2.774647 & $-3.238610^{*}$ & $-3.1444441^{*}$ \\
HIMP & 1.324583 & -1.884474 & $-3.414912^{*}$ & $-4.943334^{*}$ \\
IMPMACH & 1.238569 & 1.487436 & $-2.302542^{*}$ & $-3.467462^{*}$ \\
& & & & \\
China(C) & & & & $-3.456925^{*}$ \\
HDI & 1.8878748 & 1.9773736 & $3.3737412^{*}$ & $-5.687771^{*}$ \\
HEXP & 3.494894 & 0.8984783 & $-1.374649^{* *}$ & $-3.533459^{*}$ \\
IFDI & 2.099894 & 1.2833838 & $0.333949^{*}$ & $-4.907333^{* *}$ \\
RGDP & 2.298934 & -1.239399 & $-3.302934^{* *}$ & $-5.333955^{* *}$ \\
HIMP & 1.988473 & -0.393948 & $-3.788345^{*}$ & $-5.333589^{*}$ \\
IMPMACH & 1.998887 & -2.388489 & $-4.522299^{* *}$ & \\
& & & & \\
India(I) & & & & $-3.361598^{* *}$ \\
HDI & 1.099895 & -0.393838 & $-2.3736361^{* *}$ & $-4.766547^{* * *}$ \\
HEXP & 2.399488 & 1.399393 & $-3.3837373^{* *}$ & $-4.456482^{*}$ \\
IFDI & 0.337488 & -1.394944 & $-5.3938838^{*}$ & $-3.345184^{*}$ \\
RGDP & 0.199884 & -2.376373 & $-6.3837373^{* *}$ & $-5.565380^{*}$ \\
HIMP & 0.998940 & -1.393934 & $-4.2336736^{*}$ & \\
IMPMACH & 2.098484 & -1.309948 & $-5.3939388^{* *}$ & - \\
\hline N & & & & \\
\hline
\end{tabular}

Note: ${ }^{*}, * *$ and ${ }^{* * *}$ implies $1 \%, 5 \%$ and $10 \%$ levels of significance, respectively.

Table 2: Phillips-Perron (PP) Test Results

\begin{tabular}{|c|c|c|c|c|}
\hline Variables & $\begin{array}{l}\text { Level } \\
\text { Constant } \\
\text { without Trend }\end{array}$ & $\begin{array}{l}\text { Constant } \\
\text { with Trend }\end{array}$ & $\begin{array}{l}\text { First Difference } \\
\text { Constant } \\
\text { without Trend }\end{array}$ & $\begin{array}{l}\text { Constant } \\
\text { with Trend }\end{array}$ \\
\hline \multicolumn{5}{|c|}{ Malaysia (M) } \\
\hline HDI & -1.201432 & -2.245592 & $-5.144889^{*}$ & $-5.057306^{*}$ \\
\hline HEXP & 3.924001 & 0.725865 & $-3.135526^{* *}$ & $-4.07412^{* *}$ \\
\hline IFDI & -1.275166 & -2.664606 & $-7.202274^{*}$ & $-7.096805^{*}$ \\
\hline RGDP & 2.822786 & -0.738637 & $-4.232497 *$ & $-5.174591 *$ \\
\hline HIMP & 1.976495 & -0.852797 & $-4.400720^{*}$ & $-4.860987^{*}$ \\
\hline IMPMACH & 1.571491 & -1.210226 & $-4.900783^{*}$ & $-5.407357^{*}$ \\
\hline \multicolumn{5}{|l|}{ Thailand (T) } \\
\hline HDI & -1.120844 & -1.745726 & $-2.89435^{* * *}$ & -2.801947 \\
\hline HEXP & 3.588824 & 1.024137 & $-5.627780^{*}$ & $-6.489557^{*}$ \\
\hline IFDI & 1.384242 & -1.832620 & $-6.052339 *$ & $-7.737240^{*}$ \\
\hline RGDP & 2.266872 & -0.929186 & $-3.302965^{* *}$ & $-3.89165^{* *}$ \\
\hline HIMP & 1.908789 & -0.076366 & $-3.954526^{*}$ & $-4.380714^{*}$ \\
\hline IMPMACH & 1.175334 & -1.470557 & $-3.455271^{* *}$ & $-4.975931^{*}$ \\
\hline \multicolumn{5}{|l|}{ Nigeria(N) } \\
\hline HDI & 0.439370 & -0.148130 & $-2.65569^{* * *}$ & -2.604309 \\
\hline HEXP & 2.320468 & 0.972072 & $-3.30182^{* *}$ & $-3.74274^{* *}$ \\
\hline IFDI & 1.763926 & 0.704361 & $-5.641124^{*}$ & $-6.086636^{*}$ \\
\hline RGDP & 0.018424 & -2.356968 & $-6.769487 *$ & $-6.689742^{*}$ \\
\hline HIMP & -0.809650 & -1.275888 & $-4.613034 *$ & $-4.607808^{*}$ \\
\hline IMPMACH & 1.599318 & -0.295587 & $-5.888616^{*}$ & $-6.383675^{*}$ \\
\hline
\end{tabular}




\begin{tabular}{|c|c|c|c|c|}
\hline \multicolumn{5}{|c|}{$\begin{array}{c}\text { Journal of Economics and Behavioral Studies (ISSN: 2220-6140) } \\
\text { Vol. 8, No. 6, pp. 127-145, December } 2016\end{array}$} \\
\hline \multicolumn{5}{|l|}{ South Africa (S) } \\
\hline HDI & -1.736632 & 1.245592 & $-4.345889 * *$ & $-3.789306^{*}$ \\
\hline HEXP & 2.787301 & 0.725865 & $-4.134526^{*}$ & $-4.789412^{* *}$ \\
\hline IFDI & 1.776866 & 2.978606 & $-5.778274^{* *}$ & $-5.45505^{*}$ \\
\hline RGDP & 2.444486 & -0.738637 & $-3.666497^{*}$ & $-5.986791 *$ \\
\hline HIMP & 1.097695 & -1.374797 & $-4.345720^{*}$ & $-4.845787^{*}$ \\
\hline IMPMACH & 2.354671 & -1.447226 & $-3.456783^{*}$ & $-4.448957^{*}$ \\
\hline \multicolumn{5}{|l|}{ China (C) } \\
\hline HDI & 1.475844 & 1.456726 & $-3.894354^{* *}$ & -3.801947 \\
\hline HEXP & 2.846824 & 1.566137 & $-4.634559 * * *$ & $-6.489557^{*}$ \\
\hline IFDI & -1.384672 & -1.433620 & $-6.056789 *$ & $-2.737240^{*}$ \\
\hline RGDP & 2.264645 & -0.929445 & $-4.302365^{*}$ & $-3.89165^{* *}$ \\
\hline HIMP & 2.908748 & -0.878774 & $-2.444526^{*}$ & $-3.380714^{*}$ \\
\hline IMPMACH & 1.364734 & -1.577373 & $-2.345271^{* *}$ & $-3.975931 *$ \\
\hline \multicolumn{5}{|l|}{ India(I) } \\
\hline HDI & 1.877370 & -0.144746 & $-3.65569^{* *}$ & $-3.604333^{*}$ \\
\hline HEXP & 2.665468 & 0.445072 & $-3.398682^{* *}$ & $-3.758579^{* *}$ \\
\hline IFDI & 2.665926 & 0.345361 & $-4.786124^{*}$ & $-4.086636^{*}$ \\
\hline RGDP & 1.443424 & -2.334968 & $-5.456487 *$ & $-6.684872^{*}$ \\
\hline HIMP & -0.449650 & -1.275888 & $-4.556034^{*}$ & $-4.699588^{*}$ \\
\hline IMPMACH & 1.444318 & 1.3455587 & $-3.345136^{*}$ & $-5.458475^{*}$ \\
\hline \multicolumn{5}{|c|}{ Note: ${ }^{*},{ }^{* *}$ and ${ }^{* * *}$ implies $1 \%, 5 \%$ and $10 \%$ levels of significance, respectively. } \\
\hline \multicolumn{5}{|c|}{ First Difference } \\
\hline Variables & $\begin{array}{l}\text { Constant } \\
\text { without Trend }\end{array}$ & $\begin{array}{l}\text { Constant } \\
\text { with Trend }\end{array}$ & $\begin{array}{l}\text { Constant } \\
\text { without Trend }\end{array}$ & $\begin{array}{l}\text { Constant } \\
\text { with Trend }\end{array}$ \\
\hline \multicolumn{5}{|l|}{ Malaysia(M) } \\
\hline HDI & $0.61139 * *$ & 0.070516 & 0.055752 & 0.055499 \\
\hline HEXP & $0.68224^{* *}$ & $0.220127^{*}$ & 0.235124 & 0.084125 \\
\hline IFDI & $0.540016^{* *}$ & 0.071602 & 0.068869 & 0.060269 \\
\hline RGDP & $0.717740^{* *}$ & $0.209631^{* *}$ & 0.160438 & 0.053142 \\
\hline HIMP & $0.691270^{* *}$ & $0.193286^{* *}$ & 0.113604 & 0.061408 \\
\hline IMPMACH & $0.676906^{* *}$ & $0.193454^{* *}$ & 0.071836 & 0.057960 \\
\hline \multicolumn{5}{|l|}{ Thailand(T) } \\
\hline HDI & $0.569937^{* *}$ & 0.075514 & 0.062453 & 0.060117 \\
\hline HEXP & $0.690808^{* *}$ & $0.213009^{* *}$ & 0.192955 & 0.103680 \\
\hline IFDI & $0.766940^{*}$ & $0.208883^{* *}$ & 0.263632 & $0.169095^{* *}$ \\
\hline RGDP & $0.710045^{* *}$ & $0.183612^{* *}$ & 0.435652 & 0.063018 \\
\hline HIMP & $0.699347^{* *}$ & $0.165347^{* *}$ & 0.119382 & 0.098581 \\
\hline IMPMACH & $0.683356^{* *}$ & $0.155069^{* *}$ & 0.266995 & 0.091497 \\
\hline \multicolumn{5}{|l|}{ Nigeria(N) } \\
\hline HDI & $0.325089 * *$ & $0.14051^{* * *}$ & 0.293300 & $0.158950^{* *}$ \\
\hline HEXP & $0.507892^{* *}$ & $0.14550^{* * *}$ & 0.195006 & $0.178243^{* *}$ \\
\hline IFDI & $0.745004^{*}$ & $0.13006^{* * *}$ & 0.315861 & 0.117715 \\
\hline RGDP & $0.736431^{* *}$ & 0.072152 & 0.116336 & 0.105210 \\
\hline HIMP & $0.414510^{* *}$ & 0.112198 & 0.173065 & 0.133714 \\
\hline IMPMACH & $0.648086^{* *}$ & $0.14437^{* * *}$ & 0.321293 & 0.109837 \\
\hline \multicolumn{5}{|l|}{ South Africa (S) } \\
\hline HDI & $0.587939 * *$ & 0.234516 & 0.127752 & 0.048479 \\
\hline
\end{tabular}




\begin{tabular}{|c|c|c|c|c|}
\hline \multicolumn{5}{|c|}{$\begin{array}{c}\text { Journal of Economics and Behavioral Studies (ISSN: 2220-6140) } \\
\text { Vol. 8, No. 6, pp. 127-145, December } 2016\end{array}$} \\
\hline HEXP & $0.689880^{* *}$ & $0.345127^{*}$ & 0.267364 & 0.048745 \\
\hline IFDI & $0.540484^{* *}$ & $0.374647^{*}$ & 0.064848 & 0.049589 \\
\hline RGDP & $0.714983^{* *}$ & $0.364731^{* *}$ & 0.164947 & 0.054477 \\
\hline HIMP & $0.8498370^{* *}$ & $0.4784886^{* *}$ & 0.113487 & 0.061457 \\
\hline IMPMACH & $0.0984806^{* *}$ & $0.1494944^{* *}$ & 0.455836 & 0.057547 \\
\hline \multicolumn{5}{|l|}{ China(C) } \\
\hline HDI & $0.3454937^{* *}$ & 0.485859 & 0.344453 & 0.160117 \\
\hline HEXP & $0.5564808^{* *}$ & $0.254858^{* *}$ & 0.846955 & 0.149980 \\
\hline IFDI & $0.3455440^{*}$ & $0.258595^{* *}$ & 0.646532 & 0.169044 \\
\hline RGDP & $0.7347665^{* *}$ & $0.148585^{* *}$ & 0.847452 & 0.063456 \\
\hline HIMP & $0.6099585^{* *}$ & $0.222284^{* *}$ & 0.147482 & 0.094555 \\
\hline IMPMACH & $0.6846747^{*}$ & $0.484949^{* *}$ & 0.276487 & 0.093455 \\
\hline \multicolumn{5}{|l|}{ India(N) } \\
\hline HDI & $0.8747748^{* *}$ & $0.140457^{* * *}$ & 0.294674 & 0.158954 \\
\hline HEXP & $0.5489333^{*}$ & $0.1458595^{* *}$ & 0.195006 & $0.178553^{* *}$ \\
\hline IFDI & $0.7454857^{*}$ & $0.135586^{* * *}$ & 0.347484 & 0.117456 \\
\hline RGDP & $0.5958474^{* *}$ & $0.075859 *$ & 0.348496 & 0.557810 \\
\hline HIMP & $0.4147585^{* *}$ & 0.154575 & 0.149847 & 0.157614 \\
\hline IMPMACH & $0.6458990^{* *}$ & $0.194859^{* *}$ & 0.347567 & 0.475847 \\
\hline
\end{tabular}

Note: *,* and ${ }^{* * *}$ implies $1 \%, 5 \%$ and $10 \%$ levels of significance, respectively.

Augmented Dickey-Fuller (ADF) and Phillips-Perron (PP) Test Results: This test was conducted for unit roots in both first difference and levels significant. Similar to the ADF test, the PP test was conducted for unit roots in both first difference and levels for all the selected countries. The result of this analysis is reported in Table 2 (above). This result assumed stationarity of the series by the rejection of the null hypothesis, when the test statistic is less than the $1 \%, 5 \%$ and $10 \%$ levels of significance.

Table 4: Test results for Multiple Co-integrating Vectors

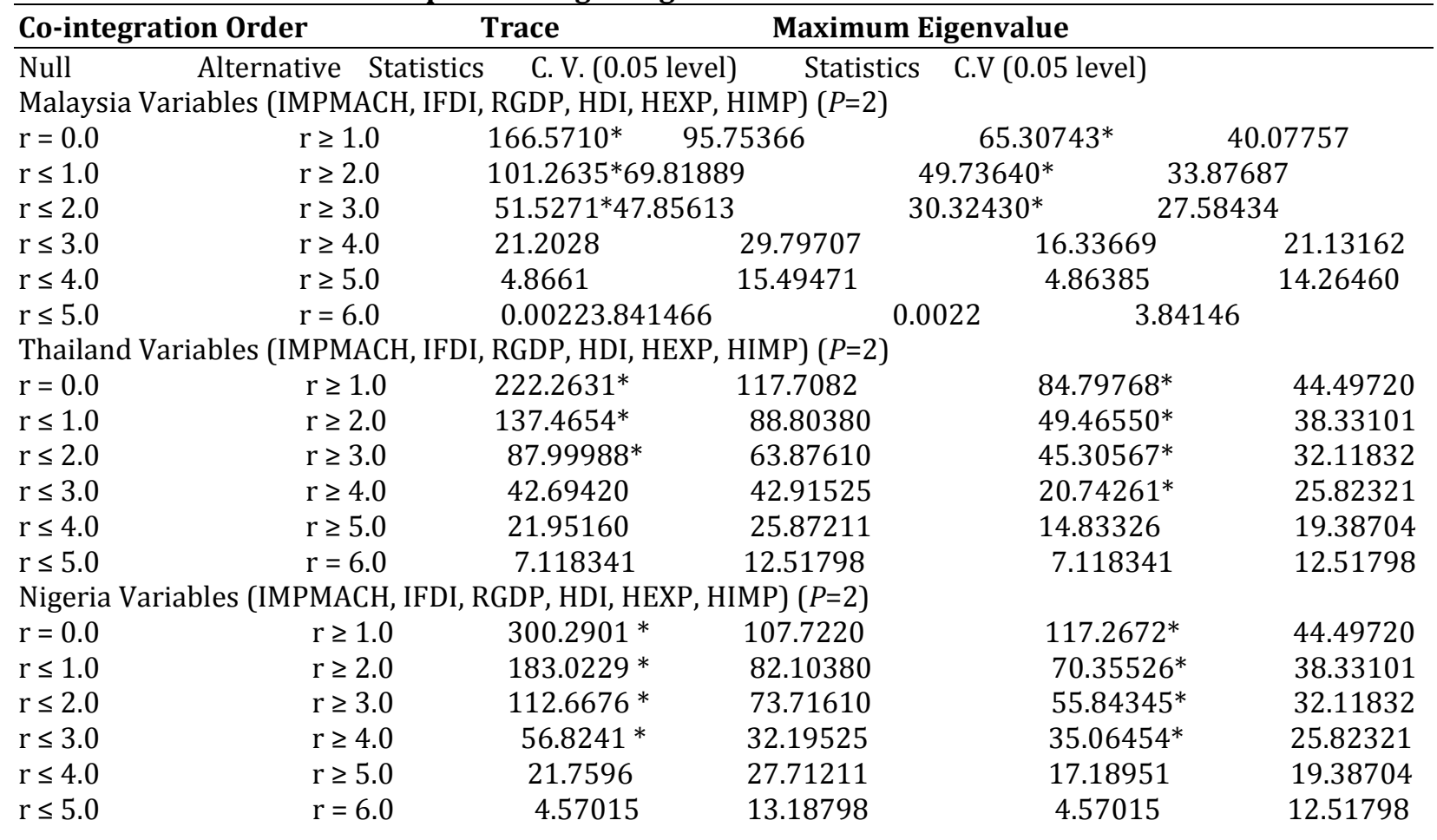




\begin{tabular}{|c|c|c|c|c|c|}
\hline \multicolumn{6}{|c|}{ South Africa Variables (IMPMACH, IFDI, RGDP, HDI, HEXP, HIMP) $(P=2)$} \\
\hline$r=0.0$ & $r \geq 1.0$ & \multicolumn{2}{|c|}{$144.4510 * 91.34566$} & \multicolumn{2}{|l|}{$75.30734^{*}$} \\
\hline$r \leq 1.0$ & $r \geq 2.0$ & \multicolumn{2}{|c|}{$122.4565 * 61.87589$} & $59.73667^{*}$ & 34.87687 \\
\hline $\mathrm{r} \leq 2.0$ & $r \geq 3.0$ & \multicolumn{2}{|c|}{$56.4571 * 44.45413$} & $40.32445^{*}$ & 24.58434 \\
\hline$r \leq 3.0$ & $r \geq 4.0$ & 34.5628 & \multirow{2}{*}{$\begin{array}{l}24.45507 \\
1145571\end{array}$} & \multicolumn{2}{|c|}{$19.34566 \quad 20.13162$} \\
\hline$r \leq 4.0$ & $r \geq 5.0$ & \multirow{2}{*}{\multicolumn{2}{|c|}{$\begin{array}{ll}6.5461 & 11.45571 \\
0.45266 .56546 & \end{array}$}} & \multirow{2}{*}{\multicolumn{2}{|c|}{$\begin{array}{r}6.86543 \\
6.84146\end{array}$}} \\
\hline$r \leq 5.0$ & $\mathrm{r}=6.0$ & & & & \\
\hline \multicolumn{6}{|c|}{ China Variables (IMPMACH, IFDI, RGDP, HDI, HEXP, HIMP) ( $P=2$ ) } \\
\hline$r=0.0$ & $r \geq 1.0$ & $143.2456^{*}$ & 127.45682 & 76.73578* & 47.98350 \\
\hline$r \leq 1.0$ & $r \geq 2.0$ & $122.4453^{*}$ & 98.80789 & $44.46320^{*}$ & 35.35461 \\
\hline $\mathrm{r} \leq 2.0$ & $r \geq 3.0$ & $81.9994^{*}$ & 73.67610 & $40.38997 *$ & 36.56772 \\
\hline$r \leq 3.0$ & $r \geq 4.0$ & 43.69456 & 49.34525 & 23.43261 & 20.48721 \\
\hline$r \leq 4.0$ & $r \geq 5.0$ & 22.95450 & 29.55211 & 15.56326 & 12.36704 \\
\hline$r \leq 5.0$ & $r=6.0$ & 9.345441 & 10.44798 & 6.668341 & 5.56798 \\
\hline \multicolumn{6}{|c|}{ India Variables (IMPMACH, IFDI, RGDP, HDI, HEXP, HIMP) $(P=2)$} \\
\hline \multicolumn{6}{|c|}{$\begin{array}{lll}r=0.0 & r \geq 1.0 & 230.45014 * \\
54.34560 & \end{array}$} \\
\hline $\begin{array}{l}r \leq 1.0 \\
38.54561\end{array}$ & $r \geq 2.0$ & \multicolumn{2}{|c|}{$193.8974 *$} & 84.34570 & $78.37895^{*}$ \\
\hline $\begin{array}{l}r \leq 2.0 \\
29.14332\end{array}$ & $r \geq 3.0$ & \multicolumn{2}{|c|}{$142.6645^{*}$} & 61.85677 & $55.84343^{*}$ \\
\hline $\begin{array}{l}r \leq 3.0 \\
21.84561\end{array}$ & $r \geq 4.0$ & \multicolumn{2}{|c|}{$86.5671 *$} & 47.93467 & $38.98754^{*}$ \\
\hline $\begin{array}{l}r \leq 4.0 \\
16.23704\end{array}$ & $r \geq 5.0$ & \multicolumn{2}{|c|}{29.57466} & 29.87243 & 19.23451 \\
\hline $\begin{array}{l}r \leq 5.0 \\
9.45798\end{array}$ & $r=6.0$ & \multicolumn{2}{|c|}{6.543152} & 11.33498 & 8.45715 \\
\hline
\end{tabular}

Note: $r$ denotes no. of co-integrating vectors; and $\left(^{*}\right)$ denotes rejection @ 95\% critical value (CV).

KPSS-Kwiatkowski-Phillips-Schmidt-Shin Test Results: The KPSS test for each of the selected countries was also conducted in the levels and first difference, to test for unit roots via the Newey-West bandwidth method (Hasbrouk, 1996; Stanley et al., 2013). Results for all the selected countries are shown in Table 3 (above). Unlike previous tests (ADF and PP tests), the null hypothesis was rejected only at levels, consequently, these further confirmed the level of integration for all variables (Masih \& Masih, 1996; Rehman et al., 2011).

Results for Multiple Co-integrating Vectors: Long-run equilibrium relationships among ITT, FDI, trade and output, in all the selected countries, were tested using multivariate co-integration (Johansen \&Juselius, 1990). This analysis is shown in Table 4.These figures were extracted using the likelihood ratio test, after a series of selection processes with a 1 through 4 lag length.

These results (Table 4) show the existence of co-integrating vectors in all the models. Specifically, there were 3 vectors in the Malaysia, South Africa and China systems (at a lag interval of 1 to 2), while four (4) cointegrating vectors were experienced in Thailand's, Nigeria 'sand India's models (lag length of 1 to 3) (Asteriou \& Hall, 2007; Clark et al., 2011). This implied that while the variables in Malaysia, South Africa and China have long-run equilibrium relationships and were adjusting via three identified channels in the shortrun, the Thailand, Nigeria and India variables did the same adjustment through 4 channels (Buchanan et al., 2012; Asteriou \& Hall, 2007; Onafowora \& Owoye, 2006).

Result of Vector Error Correction Modelling via Granger Causality: The Granger causality test was conducted to test the short-term effect of trade and FDI on ITT to the Asian and African countries. The test was done in an environment of VECM (Granger, 1969; Coe et al., 1995).However, for each system (country), the various null hypotheses $\left(\mathrm{H}_{0}\right.$ : There is no impact of ' $\mathrm{X}$ ' on ' $\mathrm{Y}$ ') was tested at different constants and levels 
of significance $(1 \%, 5 \%$, and $10 \%)$ - for both the explanatory variables and the 'group' long-run error terms (ECT ${ }_{t-1}$ terms).The results of this analysis are reported in Tables 5 to 10 (below).

Table 5: VECM results for Malaysia variables $(\mathrm{p}=2)$

\begin{tabular}{|c|c|c|c|c|c|c|c|}
\hline \multirow{4}{*}{$\begin{array}{l}\text { Variable- } \\
\text { Dependent } \\
\text { SIMPMACH }\end{array}$} & \multicolumn{4}{|c|}{$\begin{array}{l}\text { Variables-Independent } \\
\text { [Wald Test Chi Square (Significance level)] }\end{array}$} & \multirow[b]{2}{*}{$\Delta \mathrm{HDI}$} & \multirow[b]{2}{*}{$\Delta$ HEXP } & \multirow[b]{2}{*}{$\Delta$ HIMP } \\
\hline & $\triangle \mathrm{IMPMACH}$ & $\Delta$ IFDI & $\Delta$ RGI & & & & \\
\hline & ----------- & $15.0223^{*}$ & 3.3040124 & 1.602915 & 4.367073 & 0.816671 & $16.0864^{*}$ \\
\hline & & $(0.0005)$ & $(0.1917)$ & $(0.4487)$ & $(0.1126)$ & $(0.6648)$ & $(0.0011)$ \\
\hline \multirow[t]{2}{*}{$\Delta$ IFDI } & 1.033549 & ------------ & 1.595627 & $16.0791 *$ & $13.2220^{*}$ & 1.931848 & 13.6919* \\
\hline & $(0.5964)$ & & $(0.4503)$ & $(0.0003)$ & (0.0013) & $(0.3806)$ & $(0.0034)$ \\
\hline \multirow[t]{2}{*}{$\Delta$ RGDP } & $6.9187^{* *}$ & $22.4327^{*}$ & - & $14.4409^{*}$ & 2.127338 & $7.9077^{* *}$ & $25.1157^{*}$ \\
\hline & $(0.0314)$ & $(0.0001)$ & & $(0.0007)$ & $(0.3452)$ & $(0.0192)$ & $(0.0001)$ \\
\hline \multirow[t]{2}{*}{$\Delta$ HDI } & $5.5310^{* * *}$ & 0.881048 & 3.333519 & & $5.4197^{* * *}$ & 2.126841 & 1.611708 \\
\hline & $(0.0629)$ & $(0.6437)$ & $(0.1889)$ & & $(0.0665)$ & $(0.3453)$ & $(0.6567)$ \\
\hline \multirow[t]{2}{*}{$\triangle$ НHEXP } & $16.0908^{*}$ & $5.666654^{* * *}$ & $20.2809^{*}$ & $11.4211^{*}$ & --------- & 2.732798 & $8.26675^{* *}$ \\
\hline & $(0.0003)$ & (0.0588) & (0.0001) & (0.0033) & & $(0.2550)$ & $(0.0408)$ \\
\hline \multirow[t]{2}{*}{$\Delta \mathrm{HIMP}$} & $9.4670^{*}$ & 2.278973 & 4.359217 & $4.678^{* * *}$ & $5.907^{* * *}$ & ---------- & $15.2218^{*}$ \\
\hline & $(0.0088)$ & $(0.3200)$ & (0.1131) & $(0.0964)$ & $(0.0521)$ & & $(0.0016) \backslash$ \\
\hline
\end{tabular}

Note: ${ }^{*}, * *$ and ${ }^{* * *}$ indicate statistical significance at $1 \%, 5 \%$ and $10 \%$

The Malaysian, South African and Chinese systems consist of 3 (three) co-integrating vectors. Consequently, a Wald test (joint) was carried out on each of the three error correction terms.

Table 6: VECM results for Thailand variables $(p=2)$ Variables-Independent

\begin{tabular}{|c|c|c|c|c|c|c|c|}
\hline \multirow{3}{*}{$\begin{array}{l}\begin{array}{l}\text { Variable- } \\
\text { Dependent }\end{array} \\
\triangle \mathrm{IMPMACH}\end{array}$} & \multicolumn{4}{|c|}{ [Wald Test Chi Square (Significance level)] } & \multirow[b]{2}{*}{$\Delta \mathrm{HIMP}$} & \multirow[b]{2}{*}{$\mathbf{E C T}_{t-1}$} & \\
\hline & \multicolumn{2}{|c|}{$\triangle$ IMPMACH $\triangle$ IFDI $\triangle$ RGDP } & $P \quad \Delta H D$ & I $\triangle$ HEXP & & & \\
\hline & ----- & $8.207869^{* *}$ & 1.961350 & $18.30197^{*}$ & 1.622662 & 5.350815 & 19.9355* \\
\hline & & 0.0419 & 0.5805 & 0.0004 & 0.6543 & 0.1478 & 0.0002 \\
\hline$\Delta \mathrm{IFDI}$ & $6.860^{* * *}$ & -------- & 1.510704 & $16.92722^{*}$ & 2.403152 & 5.888746 & $24.9819 *$ \\
\hline & 0.0765 & & 0.6798 & 0.0007 & 0.4930 & 0.1172 & 0.00001 \\
\hline$\triangle \mathrm{RGDP}$ & 1.543045 & $6.59030^{* * *}$ & ------- & 3.373826 & $8.3045^{* *}$ & $10.526^{* *}$ & $10.526^{* *}$ \\
\hline & 0.6724 & 0.0862 & & 0.3375 & 0.0401 & 0.0146 & 0.0146 \\
\hline$\Delta \mathrm{HDI}$ & $48.7271^{*}$ & $9.798834^{* *}$ & $9.3608^{* *}$ & -------- & $24.7488^{*}$ & $8.5058^{* *}$ & 13.8349* \\
\hline & 0.00001 & 0.0204 & 0.0249 & & 0.00001 & 0.0366 & 0.4321 \\
\hline$\Delta \mathrm{HEXP}$ & 0.668981 & $8.644371^{* *}$ & 4.853424 & $20.29062 *$ & ------- & $9.9160^{* *}$ & $37.0155^{*}$ \\
\hline & 0.8805 & 0.0344 & 0.1829 & 0.0001 & & 0.0193 & 0.0001 \\
\hline$\Delta$ HIMP & 5.454319 & $9.565928^{* *}$ & 3.713398 & $17.45746^{*}$ & 2.028492 & ------- & $28.5783^{*}$ \\
\hline & 0.1414 & 0.0226 & 0.2941 & 0.0006 & 0.5665 & & 0.0001 \\
\hline
\end{tabular}

Note: ${ }^{*}, * *$ and ${ }^{* * *}$ indicate statistical significance at $1 \%, 5 \%$ and $10 \%$ 
Table 7: VECM results for Nigeria variables $(\mathrm{p}=2)$

Variables-Independent

Variable- [Wald Test Chi Square (Significance level)]

Dependent $\Delta$ IMPMACH $\Delta$ IFDI $\Delta$ RGDP $\Delta$ HDI $\Delta$ HEXP $\Delta$ HIMP $^{\text {ECT }}{ }_{t-1}$

\begin{tabular}{llllllll}
\hline$\Delta$ IMPMACH & ----- & 0.774603 & $13.2586^{*}$ & $6.84582^{* * *}$ & $9.0264^{* *}$ & 3.618038 & $20.3855^{*}$ \\
& & 0.8555 & 0.0041 & 0.0770 & 0.0289 & 0.3058 & 0.0004 \\
$\Delta$ IFDI & 4.581385 & ------ & $13.27705^{*}$ & $13.39065^{*}$ & $16.9366^{*}$ & $10.123^{* *}$ & $25.2264^{*}$ \\
& 0.2051 & & 0.0041 & 0.0039 & 0.0007 & 0.0175 & 0.00001 \\
$\Delta$ RGDP & 2.813294 & $16.6522^{*}$ & ----- & $7.57411^{* * *}$ & 2.172380 & $7.059^{* * *}$ & $23.0014^{*}$ \\
& 0.4213 & 0.0008 & & 0.0557 & 0.5374 & 0.0700 & 0.0001 \\
$\Delta$ HDI & 1.645923 & 0.036294 & 4.743651 & ----- & 5.298446 & 0.434144 & 4.623892 \\
& 0.6490 & 0.9982 & 0.1916 & & 0.1512 & 0.9331 & 0.3281 \\
$\Delta$ HEXP & $6.668^{* * *}$ & 2.62633 & $21.9823^{*}$ & $17.17398^{*}$ & ------- & $15.1570^{*}$ & $32.0661^{*}$ \\
& 0.0832 & 0.4529 & 0.0001 & 0.0007 & & 0.0017 & 0.00001 \\
$\Delta$ HIMP & $8.8948^{* *}$ & $9.6301^{* *}$ & 2.902335 & 2.600274 & $6.994^{* * *}$ & ------ & $17.3805^{*}$ \\
& 0.0307 & 0.0220 & 0.4069 & 0.4574 & 0.0721 & & 0.0016 \\
\hline
\end{tabular}

Note: ${ }^{*},{ }^{* *}$ and ${ }^{* * *}$ indicate statistical significance at $1 \%, 5 \%$ and $10 \%$

Table 8: VECM results for South Africa variables $(p=2)$

\begin{tabular}{|c|c|c|c|c|c|c|c|}
\hline \multirow{2}{*}{$\begin{array}{l}\text { Variable- } \\
\text { Dependent }\end{array}$} & \multicolumn{7}{|c|}{$\begin{array}{l}\text { Variables-Independent } \\
\text { [Wald Test Chi Square (Significance level)] }\end{array}$} \\
\hline & $\begin{array}{l}\triangle \text { IMPMACH } \\
\text { ECT }_{t-1}\end{array}$ & $\Delta$ IFDI & & GDP & $\Delta \mathrm{HDI}$ & $\triangle H E X P$ & $\Delta$ HIMP \\
\hline$\triangle \mathrm{IMPMACH}$ & ------------ & $\begin{array}{l}18.5623^{* *} \\
(0.0345)\end{array}$ & $\begin{array}{l}2.234124 \\
(0.2945)\end{array}$ & $\begin{array}{l}2.45665 \\
(0.6687)\end{array}$ & $\begin{array}{l}3.457073 \\
(0.1566)\end{array}$ & $\begin{array}{l}2.789671 \\
(0.6234)\end{array}$ & $\begin{array}{l}21.564^{* *} \\
(0.03311)\end{array}$ \\
\hline$\Delta \mathrm{IFDI}$ & $\begin{array}{l}1.234449 \\
(0.54544)\end{array}$ & & $\begin{array}{l}1.67827 \\
(0.4785)\end{array}$ & $\begin{array}{l}16.0744^{*} \\
(0.0343)\end{array}$ & $\begin{array}{l}13.25660^{*} \\
(0.0015)\end{array}$ & $\begin{array}{l}2.76848 \\
(0.4506)\end{array}$ & $\begin{array}{l}13.8909^{*} \\
(0.0067)\end{array}$ \\
\hline$\Delta \mathrm{RGDP}$ & $\begin{array}{l}7.56687^{* *} \\
(0.0345)\end{array}$ & $\begin{array}{l}20.3478^{*} \\
(0.00451)\end{array}$ & & $\begin{array}{l}14.4766^{*} \\
(0.0099)\end{array}$ & $\begin{array}{l}2.567558 \\
(0.35672)\end{array}$ & $\begin{array}{l}7.4567^{* *} \\
(0.0166)\end{array}$ & $\begin{array}{l}25.1157^{*} \\
(0.01101)\end{array}$ \\
\hline$\Delta \mathrm{HDI}$ & $\begin{array}{l}15.3410^{* * *} \\
(0.0559)\end{array}$ & $\begin{array}{l}16.48554^{* *} \\
(0.0035)\end{array}$ & $\begin{array}{l}18.4456^{* *} \\
(0.03489)\end{array}$ & ----------- & $\begin{array}{l}7.4197^{* * *} \\
(0.0575)\end{array}$ & $\begin{array}{l}22.5674^{* *} \\
(0.0333)\end{array}$ & $\begin{array}{l}21.5679^{* *} \\
(0.01877)\end{array}$ \\
\hline$\triangle \mathrm{HEXP}$ & $\begin{array}{l}14.0458^{*} \\
(0.0093)\end{array}$ & $\begin{array}{l}9.63489 * * \\
(0.0577)\end{array}$ & $\begin{array}{l}21.3455^{*} \\
(0.0034)\end{array}$ & $\begin{array}{l}21.47871^{*} \\
(0.0056)\end{array}$ & - & $\begin{array}{l}2.75688 \\
(0.45600)\end{array}$ & $\begin{array}{l}9.96675^{* *} \\
(0.0466)\end{array}$ \\
\hline$\Delta \mathrm{HIMP}$ & $\begin{array}{l}8.34570^{*} \\
(0.0458)\end{array}$ & $\begin{array}{l}2.456673 \\
(0.3455)\end{array}$ & $\begin{array}{l}3.45617 \\
(0.1341)\end{array}$ & $\begin{array}{l}5.678^{* *} \\
(0.0988)\end{array}$ & $\begin{array}{l}8.9807^{* * *} \\
(0.0556)\end{array}$ & ---------- & $\begin{array}{l}15.4568^{*} \\
(0.0019)\end{array}$ \\
\hline
\end{tabular}

Note: ${ }^{*}, * *$ and ${ }^{* * *}$ indicate statistical significance at $1 \%, 5 \%$ and $10 \%$

Table 9: VECM results for China variables $(p=2)$

Variables-Independent

[Wald Test Chi Square (Significance level)]

\begin{tabular}{|c|c|c|c|c|c|c|c|}
\hline \multirow{2}{*}{$\begin{array}{l}\text { Variable- } \\
\text { Dependent } \\
\triangle I M P M A C H\end{array}$} & \multicolumn{2}{|c|}{$\triangle$ IMPMACH $\triangle$ IFDI $\triangle$ RGDP } & $\Delta$ HDI & \multicolumn{2}{|c|}{$\Delta$ HEXP $\triangle$ HIMP } & \multicolumn{2}{|c|}{$\mathbf{C T}_{t-1}$} \\
\hline & ----- & $9.34586^{* *}$ & 2.22230 & 13.45197* & 1.98733 & 5.543675 & $20.3455^{*}$ \\
\hline & & 0.0487 & 0.4564 & 0.0034 & 0.6653 & 0.1675 & 0.0032 \\
\hline \multirow[t]{2}{*}{$\Delta \mathrm{IFDI}$} & $9.2222^{* *}$ & --------- & 4.456704 & $15.722 *$ & 2.43332 & 5.565446 & $22.4419^{*}$ \\
\hline & 0.0555 & & 0.3566 & 0.0347 & 0.3478 & 0.1567 & 0.0011 \\
\hline \multirow[t]{2}{*}{$\Delta$ RGDP } & 1.678945 & $9.76530 * *$ & -------- & 3.567826 & $9.3045^{* *}$ & $10.526^{* *}$ & $11.236^{* *}$ \\
\hline & 0.7895 & 0.08062 & & 0.3564 & 0.0444 & 0.0433 & 0.0246 \\
\hline \multirow[t]{2}{*}{$\Delta \mathrm{HDI}$} & $38.5671^{*}$ & $10.798876^{* *}$ & $9.5558^{* *}$ & ------- & $24.7488 *$ & $8.5058^{* *}$ & $51.335^{*}$ \\
\hline & 0.00331 & 0.03456 & 0.0256 & & 0.00331 & 0.0455 & 0.00221 \\
\hline \multirow[t]{2}{*}{$\triangle \mathrm{HEXP}$} & 0.54381 & $9.78971^{* *}$ & 4.65544 & $21.3462^{* *}$ & ------ & $9.9160 * *$ & $27.0995^{*}$ \\
\hline & 0.6645 & 0.0454 & 0.1829 & 0.0331 & & 0.0373 & 0.00101 \\
\hline \multirow[t]{2}{*}{$\Delta \mathrm{HIMP}$} & 2.48999 & $12.8765^{* *}$ & 3.54398 & $19.4576^{* *}$ & 2.78692 & ------- & $22.3443^{*}$ \\
\hline & 0.2544 & 0.0245 & 0.2561 & 0.0236 & 0.5555 & & 0.00122 \\
\hline
\end{tabular}


Note: $*, * *$ and ${ }^{* * *}$ indicate statistical significance at $1 \%, 5 \%$ and $10 \%$

Table 10: VECM results for India variables $(p=2)$

\begin{tabular}{|c|c|c|c|c|c|c|c|}
\hline \multirow[b]{2}{*}{$\begin{array}{l}\text { Variable- } \\
\text { Dependent }\end{array}$} & \multicolumn{4}{|c|}{$\begin{array}{l}\text { Variables-Independent } \\
\text { [Wald Test Chi Square (Significance level)] }\end{array}$} & \multirow{2}{*}{\multicolumn{2}{|c|}{$\Delta$ HEXP $\triangle$ HIMP ECT ${ }_{t}$}} & \\
\hline & $\triangle$ IMPМАCH & I $\quad$ IFDI & $\Delta$ RGDP & $\Delta$ HDI & & & \\
\hline \multirow[t]{2}{*}{$\triangle \mathrm{IMPMACH}$} & ------ & 1.34503 & $11.2456^{*}$ & $8.45682^{* *}$ & $11.6264^{* *}$ & 2.34038 & $23.444^{*}$ \\
\hline & & 0.7775 & 0.00231 & 0.0734 & 0.0339 & 0.4448 & 0.0034 \\
\hline \multirow[t]{2}{*}{$\Delta \mathrm{IFDI}$} & 3.47675 & ------- & $15.2405^{*}$ & $23.3435^{*}$ & $13.446^{*}$ & $11.443^{* *}$ & $25.288^{*}$ \\
\hline & 0.2347 & & 0.00221 & 0.00491 & 0.00227 & 0.0476 & 0.00341 \\
\hline \multirow[t]{2}{*}{$\triangle \mathrm{RGDP}$} & 2.498794 & $19.4442 *$ & ------ & $17.34511^{* * *}$ & 2.13333 & $9.999^{* * *}$ & $20.9914^{*}$ \\
\hline & 0.43877 & 0.0028 & & 0.0567 & 0.4534 & 0.0766 & 0.00331 \\
\hline \multirow[t]{2}{*}{$\Delta \mathrm{HDI}$} & 2.99743 & 1.45294 & 4.34551 & ------ & 4.24226 & 1.56774 & 4.62592 \\
\hline & 0.6490 & 0.45382 & 0.3456 & & 0.2432 & 0.3431 & 0.4481 \\
\hline \multirow[t]{2}{*}{$\triangle \mathrm{HEXP}$} & $10.348^{* *}$ & 2.45633 & $23.345^{*}$ & $11.5667^{*}$ & -------- & 15.111* & 22.961* \\
\hline & 0.0652 & 0.3429 & 0.00231 & 0.00347 & & 0.00447 & 0.00341 \\
\hline \multirow[t]{2}{*}{$\Delta \mathrm{HIMP}$} & $11.3448^{* *}$ & $12.3451^{* *}$ & 2.34535 & 2.45674 & $8.554^{* * *}$ & -------- & $15.665^{*}$ \\
\hline & 0.0443 & 0.0420 & 0.4349 & 0.4564 & 0.0779 & & 0.0036 \\
\hline
\end{tabular}

Note: ${ }^{*}{ }^{* *}$ and ${ }^{* * *}$ indicate statistical significance at $1 \%, 5 \%$ and $10 \%$

In addition, Tables 6, 7 and 10 also show the Granger-causality result for Thailand, Nigeria and India's models respectively. The model of these three countries exhibited 4 terms. The Wald test Chi Square result for all the countries, showed a causal effect in the short-run. These effects were both running bidirectionally and unidirectionally for all the countries. For clarity, the lead-lag linkages for each country's result in tables5, 6, 7, 8,9 and 10, is shown in figure 1 (below). In figures $1 \mathrm{a}, 1 \mathrm{~b}, 1 \mathrm{~d}$, and $1 \mathrm{e}-$ for the Malaysia, Thailand, South Africa and China models respectively - the role of international trade (HIMP and HEXP) channels in mediating technology transfers into these countries was insignificant. Only FDI was found to have contributed significantly to international technology transfers in all the countries, except in the Nigeria and India models. However, international technology transfers positively boosted economic growth in Malaysia, Nigeria, South Africa and India during the period under review.

On the contrary, trade terms seemed not to have impacted positively on the economic growth of Malaysia and South Africa, while both exports and FDI have strong linkages (bidirectional) in the two countries. Likewise, this study also observed a bidirectional linkage between international technology transfers and FDI in both the Thailand and China models. Similar linkages (bidirectional) were also observed between FDI and GDP in the models of Nigeria, South Africa and India. However, due to the strong bidirectional causal relationships between international technology transfers and FDI, it is interesting to know that FDI in China and Thailand could be said not to have altered the activities of domestic firms, this implied an active channel for international technology transfer's absorption and leading to improved export of goods and services. Consequently, international technology transfer into Thailand and China was an avenue for enhancing other channels like trade, output, and domestic capabilities (Keller, 2001, 2002). In support of similar research by Lee and Tan (2006) on selected ASEAN countries, this study observed that domestic activities actually influenced the level of technology transfers taking place in both Thailand and China - by encouraging absorption of technology from abroad. 
Figure1: Lead-lag linkages in the short-run from VECMs

1a. MALAYSIA

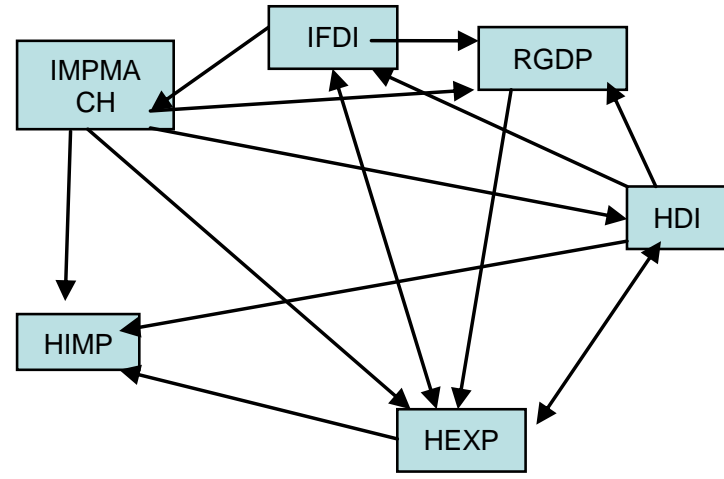

1c. NIGERIA

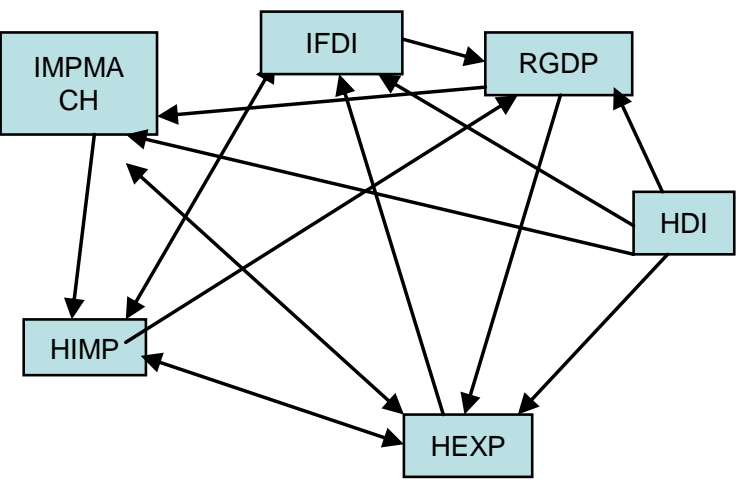

1e. CHINA

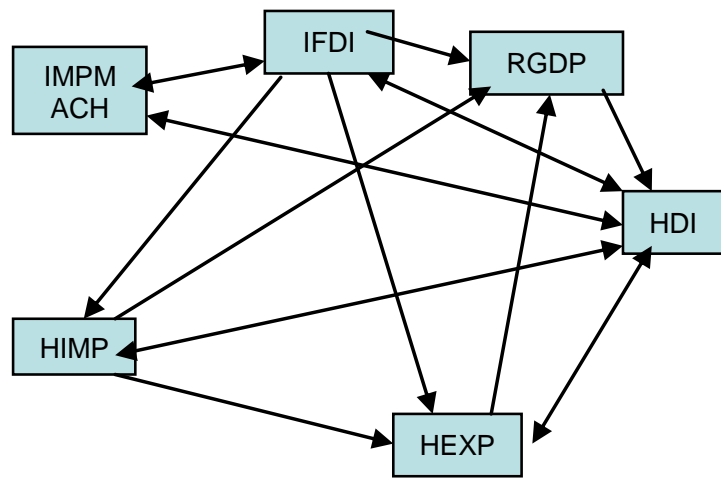

1b. THAILAND

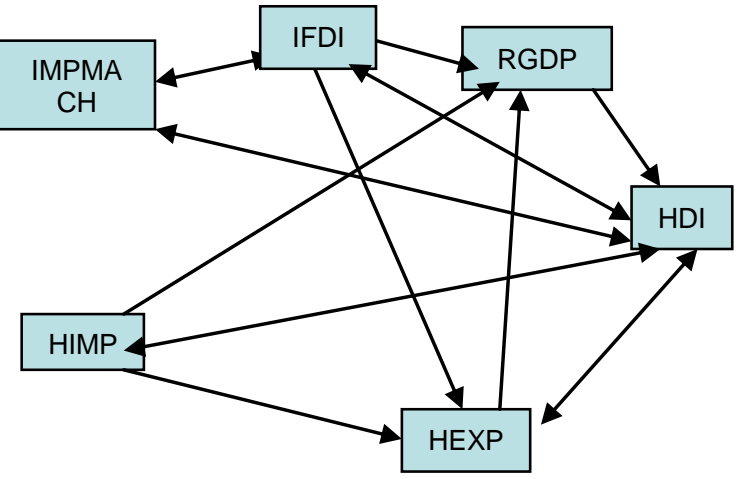

1d. SOUTH AFRICA

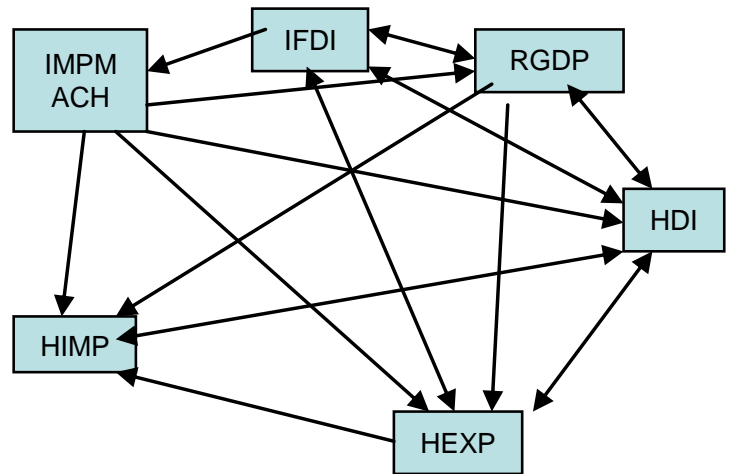

1f. INDIA

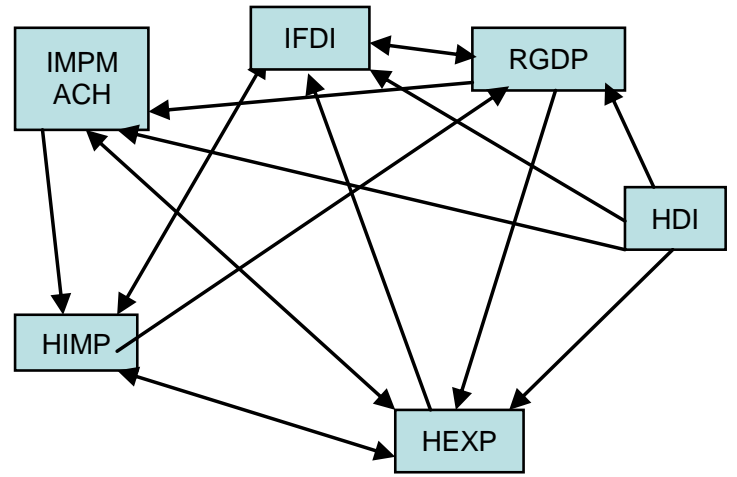

The most interesting lesson for many developing countries, both in Africa and Asia, is that this study confirmed that international technology transfers supported economic growth, export and import of goods and services and domestic investment - in both Malaysia and South Africa during the period reviewed. Hence, it could be concluded that, domestic firms' activities were not crowded out due to improvements in domestic efficiencies during the period under review (Lee \& Tan, 2006). This finding is similar to previous studies (Lee \& Tan, 2006; Johnson, 2006) in terms of economic growth and FDI linkages from developed countries. This study also revealed the significance of FDI in all the countries in terms of sustaining growth, but it failed to influence domestic investment, especially in Malaysia, Nigeria and India. In a deviation from the above analysis, this study was unable to predict a causal relationship, in the short run, between ITT and inward FDI in the case of India and Nigeria. Moreover, the study did not confirm the influence of international technology 
transfers on growth in Nigeria, Thailand and India - unlike the earlier case for Malaysia and South Africa. According to Heston, summers and Aten (2002), this may be chiefly because of a low level of development in human capital, as well as low absorptive capacities in these countries (UNDP, 2007). That notwithstanding, FDI had bidirectional relationships on RGDP and imports in Nigeria and India. This result was also similar Malaysia and South Africa (Akinlo, 2004; Anyanwu \& Yameogo, 2015).

\section{Conclusion}

This paper investigated the long-run equilibrium relationships and short-term effect of international trade and FDI on international technology transfers in selected African and Asian countries - from 1970 to 2012. Johansen and Juselius multivariate co-integration was used to test these relationships. The findings confirmed the presence of co-integrating vectors in the models of all the selected countries in this study. While the variables in the models of Malaysia, South Africa and China exhibit equilibrium relationships in the long run with each other and did the adjustment in the short-run using three established channels, the variables in the models of Thailand, Nigeria and India also exhibit the same adjustment via four identified channels. The outcome of the causality test observed both bidirectionally and unidirectionally causal effects in the short-run for all the variables. Specifically, the role of international trade (IMP and EXP01) channels in mediating technology transfers into Malaysia, Thailand, South Africa and China, were insignificant, while only FDI was found to have contributed significantly to international technology transfers in all these countries (except in the models of Nigeria and India). In addition, due to the strong bidirectional causal relationships between international technology transfers and FDI, the presence of FDI in China and Thailand also do not crowd out domestic investment. The consequential benefits on export of goods and services also mediated aggregate improvements in other channels (output, trade and domestic capabilities). This finding is similar to previous studies (Lee \& Tan, 2006; Johnson, 2006), as an improvement in inflows. Contrary to past studies (Agarwal et al., 2005; Aitken \& Harrison, 1999; Masih \& Masih, 1996; Lee \& Tan, 2006), our study could not confirm the influence of FDI on international technology transfers in Nigeria and India. Likewise, the study failed to confirm any impact on growth in Nigeria, Thailand and India, unlike the earlier case for Malaysia and South Africa (Akinlo, 2004; UNDP, 2007). Finally, all the variables in each model adjusted to equilibrium in the longrun, except for domestic investment in the Malaysian, Nigerian and Indian systems.

Recommendations and Implication: Based on our findings, the most interesting lesson for many developing countries, both in Africa and Asia, is that international technology transfers often supports domestic investment, economic growth, and export and services. The findings therefore provide overall support for the four human capital dimensions, by confirming strong positive relationships between human capital development and economic growth. In addition, since FDI was found to have contributed significantly to international technology transfers in all the countries, except in the Nigeria and India models; our model is therefore recommended as an ideal empirically study for the validation of international technology transfer for many developing economies. Our findings are also expected to help developing economies and policy makers recognize the potential of FDI, trade and local investment in enhancing technology transfers and economic growth. This study also recommends the restructuring of FDI and trade policies, in our selected countries, to increase their capacities to sustainable economic growth.

Furthermore, to reap the full benefits of international technology transfer and FDI, government policies and institutions must be strategically positioned. Countries should also understand the magnitude, its determinants, and the modes of technology transfers - which must include the generation and diffusion of technology to local firms. It is also important for African countries and other developing economies, to understand that FDI and international trade might not necessarily result in economic growth and development; rather, it may even increase economic, market, political and financial risks. Consequently, provisions should be made for the above risks associated with international trade and FDI. This is on the premise that the increase in risk premium may discourage investment by both local and international investors. Due to the inactive domestic investment and insignificant influence of FDI on technology transfer, policy-makers in these countries should quickly diversify from resource-induced FDI and trade to technologically-propelled international trade and FDI. Adequate attention must also be paid to process technology improvements, through modernization of processes and facilities. According to Solow (1956) and other studies like that of Agarwal et al. (2005) and Aitken and Harrison (1999), government policies must be 
aimed at improvement in economic growth via technological change and knowledge diffusion from developed countries(Lemoine \& Ünal-Kesenci, 2004; UNCTAD, 1999; UNCTAD, 2002).

However, care must be taken in using the output of this study, due to some inherent limitations. Similar to most empirical literature on the FDI-growth-technology transfer relationships using cross-country evidences, the first weakness relates with the likely presence of periods and country-specific omitted variables, due to the problems associated with data from most developing countries. Due to the level of poverty, corruption, illiteracy and inability of the relevant government agencies to collect and update data, most data are often not available, and even when available, they are often distorted. In addition, one of the main "inevitable" weaknesses in regression results in this study was the specifications used to examine the role of trade, FDI and growth on technology transfers, which do not include a number of other relevant variables. Further studies might consider the inclusion of these variables; chiefly among the variable are patents and research and development (R\&D) investment. Also, there is need to distinguish clearly between technologies of domestic as opposed to international origin (Mowery \& Oxley, 1995). The second limitation relate to the indicators used to measure the main variables, which might not be correctly reflecting the reality. In addition, the fact that international technology transfer occurs through a multitude of channels, makes it especially difficult to arrive at an aggregate measure of the activity - and hence to assess the contributions of the explanatory variables (Madsen, 2007). However, given the availability of multiple options in theory, the dominance of any one channel in the data would itself require explanation in future studies.

\section{References}

Agarwal, S. P., Gupta, A. \& Gandhi, G. P. (2005). Technology Transfer Trends. CACCI Journal, 2(3), 1-8.

Aitken, B. J. \& Harrison, A. E. (1999). Do domestic firms benefit from Direct Foreign Investment? Evidence from Venezuela. The American Economic Review, 89(3), 605-618.

Akaike, H. (1974). A new look at statistical model identification. IEEE Transactions on Automatic Control, 19(4), 716-723.

Akinlo, A. E. (2004). Foreign direct investment and growth in Nigeria: An empirical Investigation. Journal of Policy Modeling, 26(4), 627-639.

Al-Nasser, O. M. (2010). How does foreign direct investment affect economic growth? The role of local conditions. Latin American Business Review, 11(2), 111-139.

Anyanwu, J. C. (2012). Why Does Foreign Direct Investment Go Where It Goes? New Evidence From African Countries. Annals of Economics and Finance, 13(2), 433-470

Anyanwu, J. C. \& Yameogo, N. D. (2015). What Drives Foreign Direct Investments into West Africa? An Empirical Investigation. African Development Review, 27(3), 199-215

Aregbesola, A. R. (2014). Foreign direct investment and institutional adequacy: New Granger causality evidence from African countries. South African Journal of Economic and Management Sciences, 17(5), 557-568.

Asteriou, D. \& Hall, S. G. (2007). Applied Econometrics: A Modern approach (revised ed.), NY: Palmgrave Macmillan.

Ayanwale, A. B. \& Bamire, S. (2004). Direct Foreign Investment and firm-level productivity in the Nigerian Agro/agro-allied Sector. Journal of Social Science, 9(1), 29-36.

Ayanwale, A. B. (2007). FDI and Economic growth: Evidence from Nigeria, AERC Research Paper 165, African Economic Research Consortium, Nairobi.

Borensztein, E., Gregorio, J. \& Lee J. (1998). How does foreign direct investment affect economic growth? Journal of International Economics, 45(4), 115-135.

Buchanan, B. G., Le, Q. V. \& Rishi, M. (2012). Foreign direct investment and institutional quality: Some empirical evidence. International Review of Financial Analysis, 21(3), 81-89.

Chakraborty, C. \& Basu, P. (2002). Foreign Direct Investment and growth in India: A cointegration approach. Applied Economics, 34(9), 1061-1073.

Clark, D. P., Highfill, J., Campino, J. D. O. \& Rehman, S. S. (2011). FDI, technology spillovers, growth, and income inequality: A selective survey. Global Economy Journal, 11(2), 1-42.

Coe, D. T., Helpman, E. \& Hoffmaister, A. W. (1997). North-South R \& D spillovers. The Economic Journal, 107(4), 134-149. 
Collins, S. \& Bosworth, B. (1996). Economic growth in East Asia: Accumulation versus assimilation. Brookings Papers on Economic Activity, 2, 135-203.

Craig, J. C. (2001). Japanese Foreign Direct Investment in Thailand. Mid-Atlantic Journal of Business, 1(3), 564578.

Cuthbertson, K., Hall, S. G. \& Taylor, M. P. (1992). Applied econometric techniques, NY: Simon and Schuster, 55-105.

Deme, M. \& Graddy, D. (2006). Trade, foreign direct investment, and endogenous growth: An empirical investigation. Indian Journal of Economics and Business. Downloaded from: http://findarticles.com/p/articles/mi_m1TSD/is_2_5/ai_n25012653on 20 July 2008.

Diao, X. \& Stokke, H. E. (2005). International spillovers, productivity growth and openness in Thailand: An intertemporal general equilibrium analysis. Journal of Development Economics, 76(2), 429-450.

Doldado, J., Jenkinson, T. \& Sosvilla-Rivero, S. (1990). Cointegration and unit root. Journal of Economic Surveys, $4(3), 249-273$.

Dollar, D. (1992). Outward oriented developing economies really do grow more rapidly: Evidence from 95 LDCs, 1976-85. Economic Development and Cultural Change, 7(3), 523-544.

Fedderke, J. W. \& Romm, A. T. (2004). Growth impact and determinants of foreign direct investment into South Africa. University of Cape Town. Working Paper: 12.

Fosfuri, A., Motta, M. \& Ronde, T. (2001). Foreign direct investment and spillovers: Through workers mobility. Journal of International Economics, 53(4), 205-222.

Granger, C. W. J. (1969). Investigating causal relations by econometric models and cross spectral methods. Econometrica, 35(3), 424-438.

Granger, C. W. J. \& Newbold, P. (1974). Economic forecasting: The atheist's viewpoint. In: D. Asteriou and S. G. Hall (2007, p. 293). Applied econometrics: A modern approach (revised ed.), NY: Palmgrave Macmillan.

Granstrand, 0. (1998). Towards a theory of the technology based firm. Research Policy, 27(5), 465-489.

Grossman, G. M. \& Helpman, E. (1990). Trade, innovation, and growth. The American Economic Review, 80(2), 86-91.

Hailu, Z. A. (2010). Demand Side Factors Affecting the Inflow of Foreign Direct Investment to African Countries: Does Capital Market Matter? International Journal of Business and Management, 5(5), 104116.

Hasbrouk, J. (1996). Order characteristics and stock price evolution: An application to program trading. Journal of Financial Economics, 12(3), 365-381.

Havránek, T. \& Iršová, Z. (2010). Meta-analysis of intra-industry FDI spillovers: Updated evidence. Journal of Economics and Finance, 60(2), 151-174.

Heston, A., Summers, R. \& Aten, B. (2002). Penn World Table Version 6.1, Center for International Comparisons at the University of Pennsylvania (CICUP), accessed from: httpon1 July, 2008.

Hoekman, B. M., Maskus, K. E. \& Saggi, K. (2004). Transfer of technology to developing countries: Unilateral and multilateral policy options. World Bank Policy Research Working Paper 3332. Downloaded fromhttp://wwwwds.worldbank.org/servlet/WDSContentServer/WDSP/IB/2004/07/29/0001600 16_20040729155005/Rendered/PDF/wps3332.pdfon 21 July 2008.

Imoudu, E. C. (2012). The impact of Foreign Direct Investment on Nigeria's economic growth; 1980-2009: Evidence from the Johansen's cointegration approach. International Journal of Business and Social Science, 3(6), 122-134

Iršová, Z. \& Havránek, T. (2013). Determinants of horizontal spillovers from FDI: Evidence from a large Metaanalysis. World Development, 42(3), 1-15.

Javorcik, B. S. (2004). Does FDI increase the productivity of domestic firms? In search of Spillovers through backward linkages. The American Economic Review, 94(3), 605-627.

Jiménez, A. (2011). Political risk as a determinant of Southern European FDI in neighboring developing countries. Emerging Markets Finance and Trade, 47(4), 59-74.

Johnson, A. (2006). The Effects of FDI inflows on host country economic growth, CESIS Electronic Working paper series (No. 58). Downloaded from: http://www.infra.kth.se/cesis/documents/WP58.pdfon 31 May 2008.

Johansen, S. \& Juselius, K. (1990). Maximum likelihood estimation and inference on cointegration- with application to the demand for money. Oxford Bulletin of Economics and Statistics, 52(2), 169-210. 
Kandil, M. (2011). Financial flows to developing and advanced countries: Determinants and implications. International Journal of Development Issues, 10(1), 60-91.

Keller, W. (2001). The geography and channels of diffusion at the world's technology frontier. NBER Working Paper 8150. NBER, MA: Cambridge.

Keller, W. (2002). Trade and the transmission of technology. Journal of Economic Growth, 7(3), 5-21.

Kimura, H. \& Todo, Y. (2010). Is Foreign Aid a Vanguard of Foreign Direct Investment? A Gravity-Equation Approach. World Development, 38(4), 482-497.

Kinda, T. (2010). Investment Climate and FDI in Developing Countries: Firm-Level Evidence. World Development, 38(4), 498-513.

Klenow, P. \& Rodriguez-Clare, A. (1997). The neoclassical revival in growth economics: Has it gone too far? NBER Macroeconomics Annual, 73-103.

Kojima, K. (2000). The flying geese model of Asian economic development: origin, theoretical extensions, and regional policy implications. Journal of Asian Economics, 11(2), 375-401.

Lee, H. H. \& Tan, H. B. (2006). Technology transfer, FDI and economic growth in the ASEAN Region. Journal of the Asia Pacific Economy, 11(4), 394-410.

Leete, R. (2006). Malaysia international trade, growth, poverty reduction and human development. UNDP Reports. Accessed from: http://www.undp.org.my/index.php?option=com_content\&view=article\&id=336\&Itemid=644on 13 July, 2008.

Lemoine, F. \& Ünal-Kesenci, D. (2004). Assembly trade and technology transfer: The case of China. World Development, 32(5), 829-850.

Lim, E. (2001). Determinants of, and the relation between, FDI and growth: A summary of the recent Literature. In: V. Kathuria, (2000, pp. 343-369). Productivity spillovers from technology transfer to Indian manufacturing firms. Journal of International Development, 12(3), 234-245.

Lloyd, P. J. (1996). The role of Foreign Investment in the success of Asian. Journal of Asian Economics, 7(3), 407-433.

Madsen, J. B. (2007). Technology spillover through trade and TFP convergence: 135 years of evidence for the OECD countries. Journal of International Economics, 72(3), 464-480.

Mahe, S. A. (2005). Is globalization capable of raising living standards, through international trade in Nigeria? Downloaded from: http://www.hollerafrica.com/showArticle.php?artId=143\&catId=2on 21 July, 2008.

Markusen, J. R. (1995). Incorporating the multinational enterprise into the theory of international trade. Journal of Economic Perspectives, 9(1), 169-190.

Masih, R. \& Masih, A. M. (1996). Macroeconomic activity dynamics and Granger causality: New Evidence from a small developing economy based on a vector error-correction modeling analysis. Economic Modeling, 13(3), 407-426.

Mazenda, A. (2014). The effect of foreign direct investment on economic growth: Evidence from South Africa. Mediterranean Journal of Social Sciences, 5(10), 95-108.

Meyer, E. K. (2004). Perspectives on multinational enterprises in emerging economies. Journal of International Business Studies, 35(4), 259-276.

Mohamed, S. E. \& Sidiropoulos, M. G. (2010). Another Look at the Determinants of Foreign Direct Investment in MENA Countries: An Empirical Investigation. Journal of Economic Development, 35(2), 75-96.

Okejiri, E. (2000). Foreign technology and development of indigenous technological capabilities in the Nigerian manufacturing industry. Technology in Society, 22(2), 189-199.

Onafowora, O. A. \& Owoye, 0. (2006). An empirical investigation of budget and trade deficits: The case of Nigeria. The Journal of Developing Areas, 39(2), 115-145.

Pupphavesa, W. \& Grewe, M. (1994). Enhancing Thailand's trade policy through AFTA. TDRI Quarterly Review, $9(2), 7-12$.

Reece, C. \& Sam, A. G. (2012). Impact of pension privatization on foreign direct investment. World Development, 40(2), 291-302.

Rehman, C. A. Orangzab, \& Raza, A. (2011). Determinants of foreign direct investment and its impact on GDP growth in Pakistan. Interdisciplinary Journal of Contemporary Research in Business, 2(9), 198-205

Romer, P. (1986). Increasing returns and long-run growth. Journal of Political Economy, 94(2), 1002-1037.

Sachs, J. \& Andrew W. (1995). Economic reform and the process of global integration. Brookings Papers on Economic Activity, 1(3), 1-118. 
Saggi, K. (2002). Trade, foreign direct investment and international technology transfer: A survey. The World bank Research Observer, 17(2), 191-235.

Sasidharan, S. \& Ramanathan, A. (2007). Foreign Direct Investment and spillovers: Evidence from Indian manufacturing. International Journal of Trade and Global Markets, 1(1), 5-22.

Schwarz, G. (1978). Estimating the dimension of a model. In: D. Asteriou and S. G. Hall (2007, p. 66). Applied econometrics: A modern approach. (revised ed.), NY: Palmgrave Macmillan.

Sims, C. A. (1980). Macroeconomics and reality. Econometrica, 48(3), 1-48.

Solow, R. M. (1956). A contribution to the theory of economic growth. Quarterly Journal of Economics, 70(1), 65-94.

Sridharan, P., Vijayakumar, N. \& Chandra S. R. (2009). Causal Relationship between Foreign Direct Investment and Growth: Evidence from BRICS Countries. International Business Research, 2(4), 1-40.

Stanley, T. D., Doucouliagos, H., Giles, M., Heckemeyer, J. H., Johnston, R. J., Laroche, P., (2013). Meta-analysis of economics research reporting guidelines. Journal of Economic Surveys, 27(2), 390-394.

Strazicich, M. C., Lee, J. \& Day, E. (2004). Are incomes converging among OECD countries? Time series evidence with two structural breaks. Journal of Macroeconomics, 26(3), 131-145.

Tian, X. (2007). Accounting for sources of FDI technology spillovers: Evidence from China. Journal of International Business Studies, 38(3), 147-159.

UNCTAD. (1999). World investment report: foreign direct investment and the challenge of development, New York and Geneva: United Nations.

UNCTAD. (2002). Trade and development report 2002, New York and Geneva: United Nations.

UNCTAD. (2009). World investment report. Transnational corporations, agricultural production and development. New York and Geneva: United Nations.

UNCTAD. (2013). World investment report: Global value chains: Investment and trade for development. New York and Geneva: The United Nations.

UNCTAD. (2015). World investment report. New York: United Nations.

UNDP. (2014). United Nations Development Programme, Human Development Report (2014).

UNDP. (2007). Human development reports -indicators by tables. Accessed from: http://hdrstats.undp.org/indicators/indicators_table.cfmon 03 July 2008.

Urata, S. \& Yokota, K. (1994). Trade liberalization and productivity growth in Thailand. Developing Economies, XXXII (4), 444-459.

Usman, A. \& Ibrahim, W. (2012). Foreign Direct Investment and Monetary Union in ECOWAS Sub-Region: Lessons from Abroad. Journal of Applied Finance \& Banking, 2(4), 185-192

World Trade Organization [WTO]. (2001). Third trade policy review of Malaysia. Downloaded from: http://www.wto.org/english/tratop_e/tpr_e/tp180_e.htmon 14 July, 2008

World Trade Organization [WTO]. (2007). International trade statistics -2007. Downloaded from: http://www.wto.org/english/res_e/statis_e/its2007_e/its2007_e.pdfon 31 May 2008.

Young, A. (1994). Lessons from the East Asian NICs: A contrarian view. European Economic Review, 38(3), 964-973. 